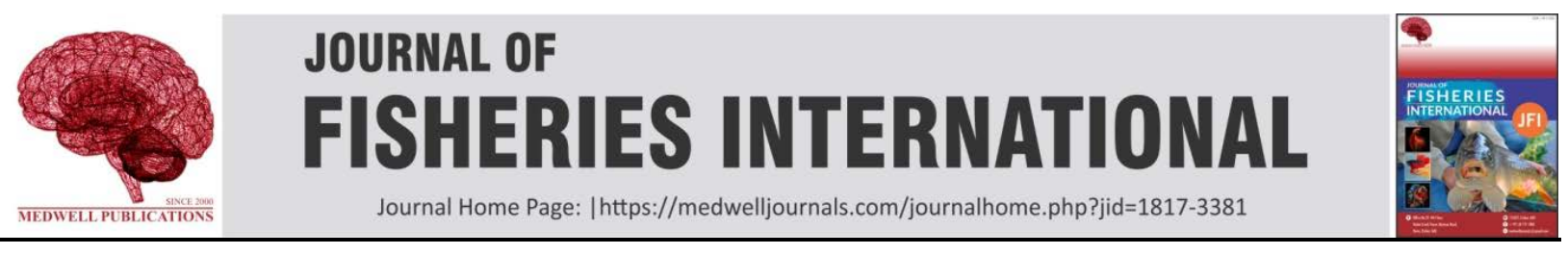

\title{
Acute Toxicity Assessment on Biochemical and Histopathological Alterations of Bleaching Powder-Exposed Fresh Water Fish Labeo rohita
}

\author{
Manisha Aswale, Rohini Ghongade, Manjit Singh Arora and Sangeeta Sinha \\ Department of Zoology, Nowrosjee Wadia College, Pune-07, Maharashtra, India
}

Key words: Bleaching powder, sub-lethal toxicity, antioxidant enzymes, histopathology, environment

\section{Corresponding Author: \\ Sangeeta Sinha \\ Department of Zoology, Nowrosjee Wadia College, Pune-07, Maharashtra, India}

Page No.: 23-31

Volume: 14 (4), 2019

ISSN:1817-3381

Journal of Fisheries International

Copy Right: Medwell Publications

\begin{abstract}
Bleaching power (Calcium hypochlorite) is commercially used as a laundry detergent and the water used for such process goes into the aquatic environment such as water resources. Quality of the water can been indicated by the fishes living in that environment. In the present study, the freshwater fish, Labeo rohita fingerlings were exposed to sub-lethal concentration of bleaching powder for 24, 48, 72 and $96 \mathrm{~h}$. Significant changes were recorded in various enzyme activities, i.e., cytotoxicity marker enzyme (LDH), anti-oxidative enzymes Catalase (CAT), Superoxide Dismutase (SOD), Glutathione Peroxidase (GPx) and Glutathione Reductase (GR) of the bleaching powder treated liver and gill tissues. Lipid peroxides were also significantly increased in liver and gills tissues exposed to bleaching powder. The histological examination of the gills of Labeo rohita revealed the deterioration of bronchial, fusion of secondary gill lamellae secondary gill lamellar epithelium due to bleaching powder. The result showed that acute bleaching powder toxicity severely affects the normal behavior and vital organs which is deleterious for the exposed fish.
\end{abstract}

\section{INTRODUCTION}

The overall ecosystem which included plants and animals was adversely affected by lots of industrial effluents like heavy metals cadmium, calcium, etc. and effluents like detergents (Rahman et al., 2013). Beaching powder is one of them. Bleaching powder also known as Calcium hypochlorite $(\mathrm{CaCIO})_{2}$ is an inorganic compound. It is marked as chlorine powder or bleach powder for water treatment and as a bleaching agent. The adverse effect of bleaching powder is widely studied in organism including humans and other mammals. (Chowdhury et al., 2012; Reddy and Rawat, 2013, Rahman et al., 2017).

One of the most important non-target aquatic organism fish, affected by detergent pollution (Rani and Kaushik, 2014). Fishes are rich in vitamins (fat-soluble vitamins $\mathrm{A}, \mathrm{D}$ and $\mathrm{E}$ and water-soluble vitamins, B complex) and minerals (especially, calcium, phosphorus, iron, selenium) (Choo and Williams, 2003; Sandhu and Lone, 2003; Salim, 2006; Butchiram et al., 2013). Therefore, fish can provide an important source of nutrients, particularly in those diets which are lacking nutritional constituents (Jawahar et al., 2015). Fish also serve as bioindicator to environmental pollution. Histopathological changes have been widely used as biomarkers in the evaluation of the health of fish exposed to contaminants, the laboratory (Thophon et al., 2003; Kaoud and El-Dahshan, 2010) and field studies. Fish is generally, considered very sensitive to all kind of environmental changes to which it is exposed.

Present study was aimed to evaluate the cytotoxic effect of bleaching powder on liver of Labeo rohita exposed to different concentration of bleaching powder for $96 \mathrm{~h}$. The oxidative stress was evaluated in terms of measuring antioxidant enzymes activities such as catalase, superoxide dismutase, glutathione peroxidase and glutathione reductase. Also, damage to lipids were estimated in terms of lipid peroxides formed under different concentrations of bleaching powder. Histopathological biomarkers were also examined in liver and gill tissues of fingerlings treated with bleaching powder.

\section{MATERIALS AND METHODS}

Collection and maintenance of animals: The Indian major carp, L. rohita (length 4-7 cm and weight 5-6 g 
were procured from government fish farm, pune, India. The test organisms were transferred to the laboratory in the plastic bags and were washed with $0.1 \% \mathrm{KM}_{\mathrm{n}} \mathrm{O}_{4}$ solution to get rid of dermal infection. Healthy fingerlings were selected and acclimated in dechlorinated tap water for 15 days; during this period they were fed with oilcake (1 g), thrice a day by dissolving in $10 \mathrm{~mL}$ of dechlorinated tap water. Water was replenished $75 \%$ on daily basis with routine cleaning of aquaria leaving no faecal matter and unconsumed food. In the present study chlorine free tap water was used which had the following physiochemical characterisitics (APHA., 2005); temperature $25 \pm 1.0^{\circ} \mathrm{C}$, $\mathrm{pH} 7.4 \pm 0.07$, salinity $0.25 \pm 0.1 \mathrm{ppt}$, dissolved oxygen $6.5 \pm 0.4 \mathrm{mg} / \mathrm{L}$, total hardness $17 \pm 0.5 \mathrm{mg} / \mathrm{L}$ and alkalinity $36 \pm 0.5 \mathrm{mg} / \mathrm{L}$.

Toxicant used: Commercial bleaching powder was purchased from Sigma Aldrich Corporation, USA (CAS No. 7778-54-3, 211389). Stock solution of bleaching powder was prepared by dissolving $1 \mathrm{~mL}$ of bleaching powder in appropriate amount of normal tap water.

Acute toxicity test: Into 5 litre plastic tubs containing 1L of test solution, twenty test animals were introduced in a static bioassay system. Experiments were carried out in replicates and a separate control was maintained. The fingerlings were not fed during the period of exposure. After conducting range finding tests, five different concentrations namely 0,10, 20, 30, 40 and 50 ppm were selected to determine the LC50 values.

Measurement of cytotoxic marker enzyme: After removal of organs (gill and liver), blotted dry with Whattman filter paper. Then $100 \mathrm{mg}$ of each tissue were homogenates $(100 \mathrm{mg} / 2.5 \mathrm{~mL}$, w/v) with $0.25 \mathrm{M}$ sucrose solution in ice cold condition (Hogeboom et al., 1948). The homogenates were centrifuged for $20 \mathrm{~min}$ at $6000 \mathrm{rpm}$ (ice cold condition) and the clear supernatant fluid was removed and used to determine the level of GOT, GPT and LDH activities. GOT and GPT activities were measured according to Reitman and Franckel (1957) at $505 \mathrm{~nm}$ against distilled water. LDH was measured using standard protocol (Wahlefeld, 1983) at $340 \mathrm{~nm}$ against distilled water. Optical density was measured with the help of a UV-spectrophotometer. Activity of all enzymes was expressed in IU/L.

Measurement of lipid damage: Oxidative damage to lipids in liver tissue under different conditions was measured in terms of pmoles of malondialdehyde equivalents formed (Devasagayam, 1986) and expressed $\%$ damage.

Measurement of antioxidant enzymes: Catalase (CAT, EC 1.11.1.6) activity was determined by the method described by Aebi. Superoxide Dismutase (SOD, EC 1.15.1.1) was assayed according to Beauchamp and Fridovich (1971). Glutathione Peroxidase (GPx, EC
1.15.1.9) activity was measured by the method of Lawrence and Burk (1976). Glutathione Reductase (GR, EC 1.8.1.7) activity was determined by the protocol of Goldberg and Spooner (1983). Enzymes activities was expressed as U/mg.

Measurement of protein: Protein was estimated following the method by Lowry et al. (1951).

Statistical analysis: The mortality (\%) data obtained were used to calculate the 24, 48, 72 and 96 h LC50 values by probit analysis method using a statistical package (Grafpad Software). ANOVA was used to compare the LC50 values of bleaching powder to test organisms after $96 \mathrm{~h}$. All experiments were repeated at least five times and data presented is average of these replicates. One-way Analysis of Variance (ANOVA) test associated with the Tukey's test was used to determine the statistical significance of the differences among experimental groups. All the statistical analyses were done using SPSS 17.0 Software.

\section{RESULTS AND DISCUSSION}

Morphometric measurements and behavioural changes: During the study the morphometric measurements of fingerlings of rohu were also taken. A morphometric measurement of fingerlings varies in weight (11.8 $\mathrm{g} \pm 2.9$ ), length (3.9 $\mathrm{cm} \pm 1.4)$, Breadth (1.2 $\mathrm{cm} \pm 0.9)$ and height $(0.5 \mathrm{~cm} \pm 0.6)$. No significant variations were observed on morphometric measurements in terms of weight, length, breadth and height (Table 1). When experimental fishes were introduced into water containing bleaching powder at higher concentrations, they started showing discomfort within few minutes and began to move rapidly. Fingerlings of Labeo rohita exhibited a variety of behavioral responses like opercular movement was 20-25 times more faster than controlled, loss of nervous control, try to jump out of media body was slimy due to mucus secretion from epithelium of gills.

To measure and evaluate the median Lethal Concentration (LC50): In the following experiment the rohu fingerling was treated with different concentrations of crystal violet ranging from 0-50 ppm. At the different concentrations of bleaching powder viz 0, 10, 20, 30, 40, 50 ppm\% mortality were 0, 22, 36, 54, 75, 100, respectively. Figure 1 shows the mortality rates and LC50's for bleaching powder was 28 ppm.

Quantitation of cytotoxic marker enzyme (LDH) under different conditions: On addition of the bleaching powder as a toxicant at different concentrations $(0,10,20$, 30, 40, $50 \mathrm{ppm})$, the specific activity of $\mathrm{LDH}$ was significantly increased with respect to the control. At the concentration of $50 \mathrm{ppm}$ bleaching powder the activity of LDH (Fig. 2 and 3) was significantly increased in liver 
Table 1: Morphometric measurements of fishes

\begin{tabular}{|c|c|c|c|c|}
\hline \multirow{2}{*}{$\begin{array}{l}\text { Concentration } \\
\text { (mg/L) }\end{array}$} & \multirow[b]{2}{*}{ Weight (g) } & \multicolumn{3}{|l|}{ Dimensions } \\
\hline & & Length $(\mathrm{cm})$ & Breadth $(\mathrm{cm})$ & Height $(\mathrm{cm})$ \\
\hline Control & $13.5 \pm 1.7$ & $7.1 \pm 0.3$ & $1.9 \pm 0.4$ & $1.1 \pm 0.5$ \\
\hline 10 ppm ВР & $09.2 \pm 0.8$ & $7.4 \pm 0.5$ & $2.4 \pm 0.3$ & $2.0 \pm 0.3$ \\
\hline 20 ppm BP & $10.4 \pm 1.2$ & $8.2 \pm 0.6$ & $1.7 \pm 0.9$ & $2.8 \pm 0.6$ \\
\hline 30 ppm BP & $13.0 \pm 1.7$ & $7.6 \pm 1.4$ & $1.6 \pm 1.3$ & $1.6 \pm 0.2$ \\
\hline 40 ppm BР & $12.2 \pm 1.2$ & $9.1 \pm 1.1$ & $2.2 \pm 0.2$ & $2.5 \pm 0.3$ \\
\hline 50 ppm BP & $08.9 \pm 2.9$ & $8.8 \pm 0.4$ & $1.3 \pm 0.4$ & $2.3 \pm 0.2$ \\
\hline
\end{tabular}

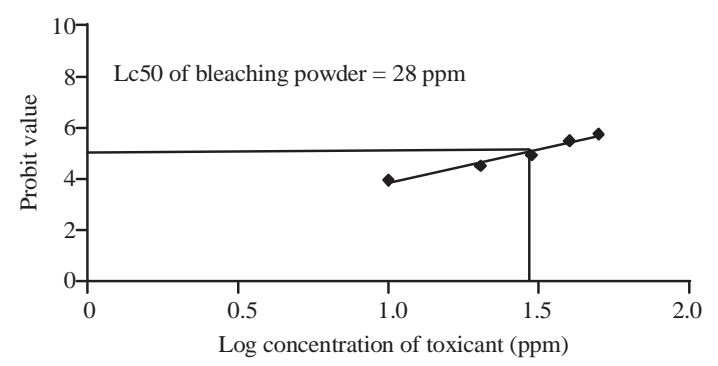

Fig. 1: The LC50 values of bleaching powder to rohu fingerlings after $96 \mathrm{~h}$ exposure
$(247 \pm 1.8 \mathrm{IU} / \mathrm{L}, \mathrm{p}<0.001)$ and gills $(142 \pm 1.1 \mathrm{IU} / \mathrm{L}$, $\mathrm{p}<0.05$ ) as compared to controls (Liver: $117 \pm 1.1$ IU/L; Gills: $54 \pm 1.7$ IU/L). The activities of GOT was also significantly increased at $50 \mathrm{ppm}$ (Liver: $107 \pm 0.7$ IU/L, $\mathrm{p}<0.001$; Gills: $76 \pm 4.0 \mathrm{IU} / \mathrm{L}, \mathrm{p}<0.05$ ) compared to controls (Liver: $57 \pm 1.1 \mathrm{IU} / \mathrm{L}$; Gills: $23 \pm 1.0 \mathrm{IU} / \mathrm{L}$ ), respectively. Similarly, the activities of GPT were also significantly increased in liver and gills tissues at $50 \mathrm{ppm}$ compared to respective controls.

Estimation of lipid peroxidation in liver tissues: Lipid peroxidation level in the liver tissue of the Labeo rohita was assessed by estimating the end product MDA in the liver and gills. It was observed that with the increases in concentration of bleaching powder the lipid peroxidation levels also increases. Lipid peroxidation was maximally observed at $50 \mathrm{ppm}$ in liver $(79 \pm 1.5 \%, \mathrm{p}<0.05)$ and gills $(91 \pm 1.6 \%$, $\mathrm{p}<0.001$ ) with respect to controls (Fig. 4), respectively.

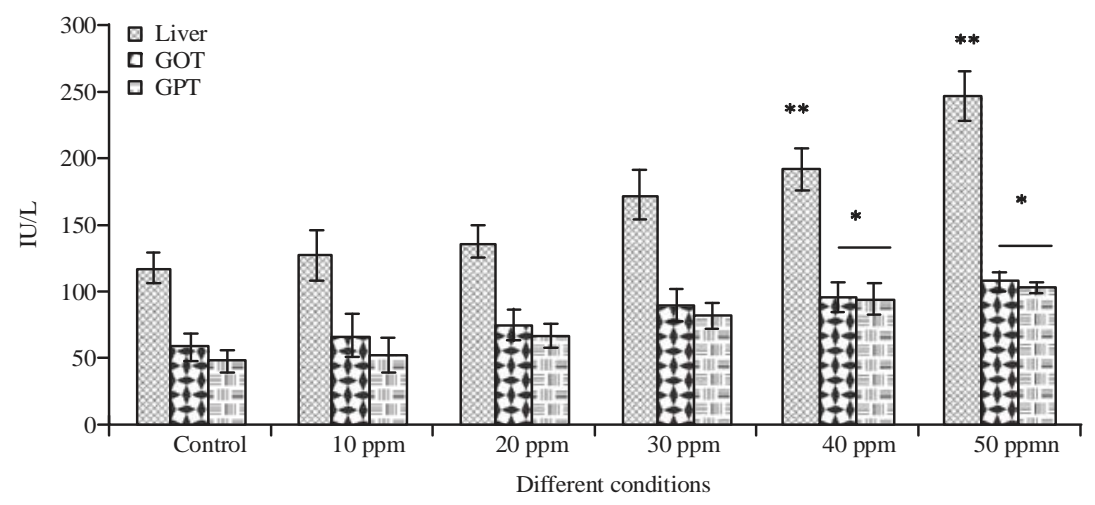

Fig. 2: Changes in the enzymological parameters (GOT, GPT and LDH) activity in the liver of a freshwater fish Labeo rohita treated with different concentration of bleaching powder. Values are means $\pm \mathrm{SE}$ of five individual observations; **Statistically significant $(\mathrm{p}<0.001)$ compared to control group; *Statistically significant $(\mathrm{p}<0.05)$ compared to control grou

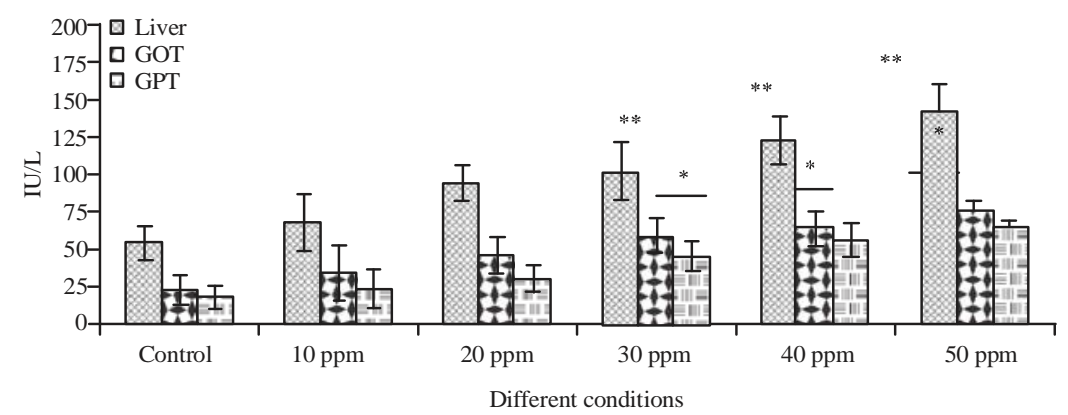

Fig. 3: Changes in the enzymological parameters (GOT, GPT and LDH) activity in the gills of a freshwater fish Labeo rohita treated with different concentration of bleaching powder. Values are means $\pm \mathrm{SE}$ of five individual observations; **Statistically significant $(\mathrm{p}<0.001)$ compared to control group; *Statistically significant $(\mathrm{p}<0.05)$ compared to control group 
Table 2: Specific activity (U/mg) of antioxidant enzymes in liver tissues under different conditions.

\begin{tabular}{lllll}
\hline $\begin{array}{l}\text { Different } \\
\text { concentration }\end{array}$ & Catalase & SOD & GPx & GR \\
\hline Control (ppm) & $801 \pm 17$ & $514 \pm 9$ & $2.4 \pm 0.1$ & $1.5 \pm 0.03$ \\
10 & $1080 \pm 38$ & $595 \pm 9$ & $2.1 \pm 0.01$ & $1.1 \pm 0.03$ \\
20 & $1257 \pm 28$ & $655 \pm 30$ & $1.5 \pm 0.2$ & $0.9 \pm 0.01$ \\
30 & $1489 \pm 12^{*}$ & $756 \pm 27 *$ & $1.4 \pm 0.01 *$ & $0.8 \pm 0.02^{*}$ \\
40 & $1592 \pm 33^{* *}$ & $838 \pm 25^{* *}$ & $1.3 \pm 0.02^{* *}$ & $0.7 \pm 0.011^{* *}$ \\
50 & $1779 \pm 20^{* *}$ & $904 \pm 14^{* *}$ & $1.2 \pm 0.01^{* *}$ & $0.6 \pm 0.02^{* *}$ \\
**Statistically & significant (p<0.001) compared to control group; \\
*Statistically significant $(\mathrm{p}<0.05)$ compared to control group
\end{tabular}

Table 3: Specific Activity (U/mg) of antioxidant enzymes in Gill tissues under different conditions.

\begin{tabular}{lllll}
\hline $\begin{array}{l}\text { Different } \\
\text { concentration }\end{array}$ & Catalase & SOD & GPx & GR \\
\hline Control (ppm) & $181 \pm 11$ & $89 \pm 15$ & $1.5 \pm 0.04$ & $1.1 \pm 0.03$ \\
10 & $256 \pm 31$ & $123 \pm 12$ & $1.4 \pm 0.01$ & $0.9 \pm 0.04$ \\
20 & $301 \pm 28$ & $189 \pm 13$ & $1.3 \pm 0.02$ & $0.7 \pm 0.03$ \\
30 & $389 \pm 11^{*}$ & $256 \pm 17^{*}$ & $1.2 \pm 0.07 *$ & $0.5 \pm 0.02$ \\
40 & $592 \pm 22^{* *}$ & $378 \pm 19 * *$ & $0.9 \pm 0.03^{* *}$ & $0.3 \pm 0.01^{* *}$ \\
50 & $869 \pm 13^{* *}$ & $504 \pm 18^{* *}$ & $0.6 \pm 0.02^{* *}$ & $0.2 \pm 0.02^{* *}$ \\
$* *$ Statistically & significant $(\mathrm{p}<0.001)$ compared to control group; \\
$*$ Statistically significant $(\mathrm{p}<0.05)$ compared to control group
\end{tabular}

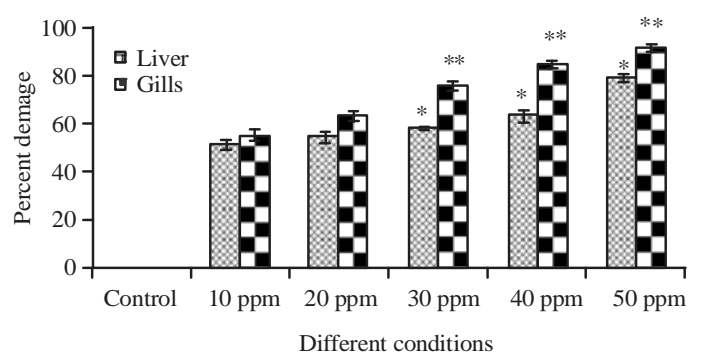

Fig. 4: Lipid peroxidation in liver tissue expressed as \% damage. Results are mean \pm SE of Ten rohu fingerlings used in each group; **Statistically significant $(\mathrm{p}<0.001)$ compared to control group; * Statistically significant $(\mathrm{p}<0.05)$ compared to control group

Estimation of antioxidant enzymes: The major Antioxidant Enzyme (AOEs) enzymes reducing oxidative stress include catalase, superoxide dismutase, glutathione peroxidase and glutathione reductase. At 50 ppm concentration of bleaching powder (Table 2) the activity (U/mg protein) of antioxidant enzymes significantly altered by 2.2 fold in catalase (1779 \pm 21$), 1.7$ fold in SOD (904 \pm 15$), 1.7$ fold in GPx (1.3 \pm 0.01$)$ and 2.2 fold in GR $(0.6 \pm 0.02)$, respectively in liver tissues of fingerlings compared to control. Similarly, these levels were significantly modulated to 4.8 fold (catalase), 5.6 fold (SOD), 0.4 fold (GPx) and 0.2 fold (GR), respectively in the gill tissues in comparison with the control group (Table 3).

Histopathological analysis of gill tissue: In the present study histological alterations were documented for gill tissues of bleaching power infected Labeo rohita fingerlings. The morphology of control Labeo rohita gill represents numerous gill arches. Primary lamella project from posterior edge of gill arch (Fig. 5). Primary lamella helps the secondary lamella to originates on superior and inferior surface. Epithelial cell covering of secondary lamella on basement membrane was supported by pillar cells. Gill arches showed clear boundaries of growth zone. Normal distribution of macrophages, endothelial cells, mucous cells and chloride cells was observed.

At 10 ppm the normal architecture of gill filaments such primary lamellae, secondary lamellae with mucus cells lying scattered on both sides. Fingerlings exposed to 20 ppm of bleaching powder showed proliferation of epithelium, lamellar fusions and loss of secondary lamellae compared to gills of control fingerlings (Fig. 1). Acute LC50 dose (30 ppm) showed no distinct secondary lamella and clumping of cells and cell debris were observed in surrounding areas. Detachment of epithelial surface in primary gill lamella was observed. There is no differentiation between acellular bone, growth zone and apical zone. Few of the basal cells showed necrosis. Fishes exposed to 40 ppm of bleaching. Powder, resulted in shortening of secondary lamella. The primary gill lamella was dilated leading to damage at various places. Basal cell layer was reduced. Destruction of mucus cells on the top of gill lamella was observed. At the higher concentration of $50 \mathrm{ppm}$ the gills of fingerlings showed degenerative, necrotic and proliferative changes in gill filaments and secondary lamellae and congestion in blood vessels of gill filaments (Fig. 5).

Fish health reflect and give a good indication of the health status of a specific aquatic ecosystem. Early toxic effects of pollution is evident on cellular or tissue level before significant changes can be identified in fish behaviour or external appearance.

Aquatic vertebrates particularly fish appear to have similar enzyme and receptor systems as in mammalian system. By changing and adapting metabolic functions, fish react to environmental toxicants. Changes in the enzymatic activities of aquatic organisms are widely used to demonstrate tissue damage and also diagnosis of fish diseases (Nemesok and Boross, 1999; Pacheco and Santos, 2002; Jawahar et al., 2015). GOT and GPT usually present within cell membranes, cytoplasm and mitochondria. The accumulation or binding of toxicants in these cells lead to damage and disintegration of cells, releasing these enzymes into blood circulation, results in increase in blood serum transaminases during stress conditions (Jeney et al., 1992; Malarvizhi et al., 2012). In aquatic monitoring increased activities of GOT and GPT indicated hepatic tissue damage. Increase in GOT and GPT activity in monocrotophos treated fish Channa punctatus indicates liver damage (Agrahari et al., 2007; Schreiber et al., 2011).

In the present study, the significant increase in GOT and GPT activity in gill and liver during acute treatment indicates that the damage of the organs due to bleaching powder toxicity or the organism tries to mitigate the toxicant induced stress by increased rate of metabolism. 

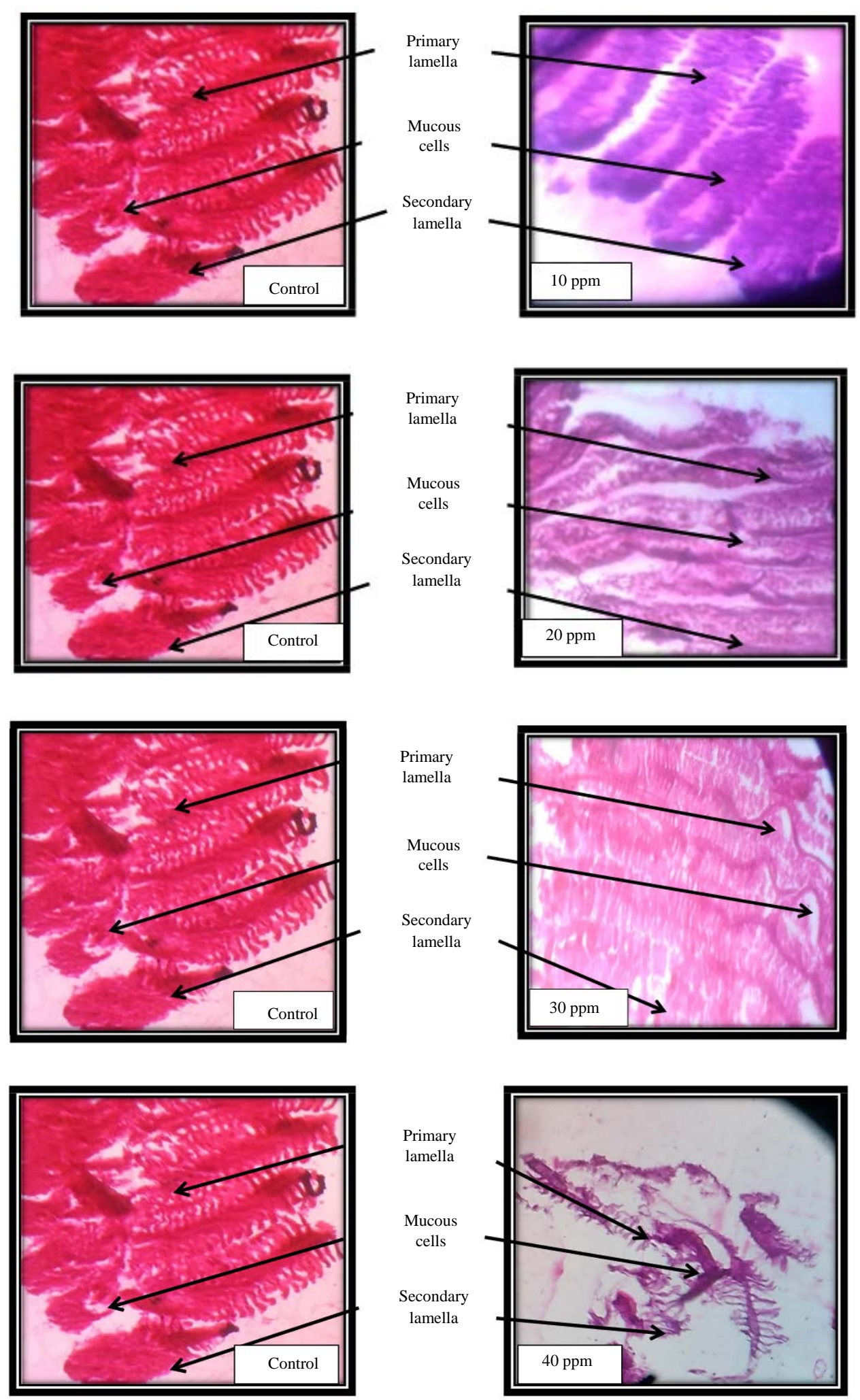

Fig. 5: Continue 

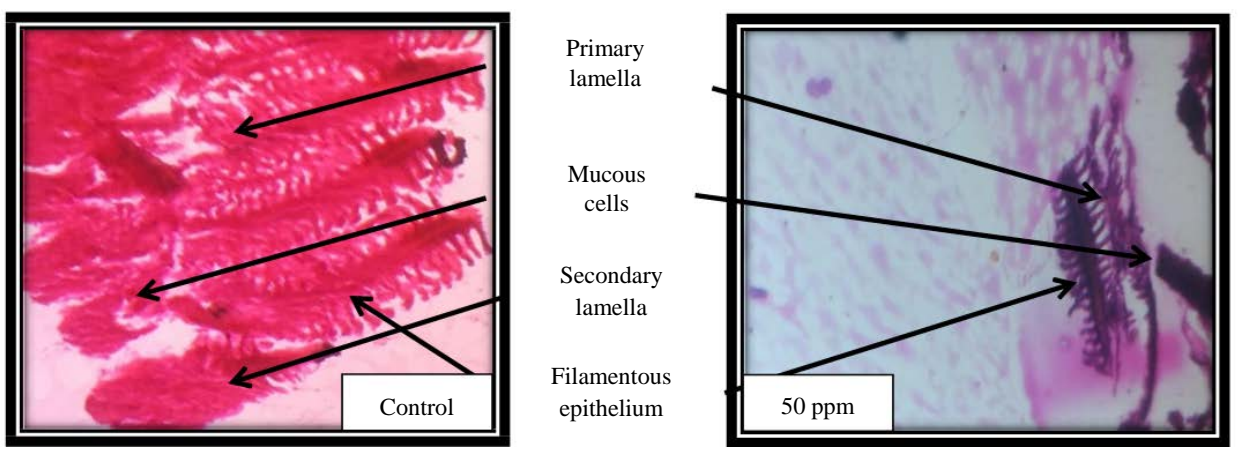

Fig. 5(a-e): Pathology of gills in control and experimental rohu fishes (400 X)

However, the observed decrease in GOT and GPT activity in gill and liver during acute treatment signifies that detoxification mechanism may not be sufficiently effective to prevent the action of the bleaching powder on the system.

LDH enzyme activity can be used as a good indicator of the anaerobic capacity of a tissue, chemical exposure and stress in fish (Tugiyono and Gagnon, 2002; Rendon-von Osten et al., 2005; Schreck and Tort, 2016). Elevated LDH activity in gills suggests that the aerobic catabolism of glycogen and glucose has shifted towards the formation of lactate which may have adverse long-term effects on the organisms (Szegletes et al., 1995; Napierska et al., 2009; Ray and Sinha, 2016). In the present study, the elevation of LDH activity in gill and liver has occurred may be due to the metabolic changes caused by the bleaching powder. Further disruption of respiratory epithelium might have caused tissue hypoxia resulting in a decrease in oxidative metabolism which may be responsible for increase in LDH activity in toxicant stressed animals (Sinha and Ray, 2018).

Peroxidation of lipids is important for aquatic animals as it contain greater amounts of highly unsaturated fatty acid than other species (Huang et al., 2004) has been reported to be major contributor to the loss of cell function under oxidative stress (Secci et al., 2016) and has usually been indicated by TBARS. In the present study the liver tissue lipid peroxidation was demonstrated by the increase in their respective TBARS levels as well as inhibition of the indigenous antioxidant enzyme after the bleaching powder experiment. Lipid peroxidation level in the liver tissue of the Labeo rohita was assessed by estimating the end product MDA in the liver. It was observed that with the increases in concentration of bleaching powder the lipid peroxidation levels also increases (Table 9). Lipid peroxidation was maximally observed at $50 \mathrm{ppm}(69.33 \pm 1.52 \%, \mathrm{p}<0.001)$ with respect to control (Fig. 3).

Antioxidant defense enzymes such as CAT and SOD have a remarkable importance for aquatic organisms because these enzymes protect them from free radicals that cause oxidative stress. The present results showed that SOD and CAT activities increased with increase in bleaching powder concentration. The increase in CAT activity may be related to cope with the increased oxidative stress caused by metal exposures. The SOD-CAT system, the first line of defense system against oxidants varied according to the response of fish antioxidant system to counteract with the toxicity of hardness and metal exposures (Basha and Rani, 2003; Vutukuru et al., 2006; Atli and Canli, 2010; Nabi et al., 2017). Li et al. (2009) reported a slight increase in SOD and CAT activity in CBZ-treated fish O. mykiss during the first period (7 days). In rainbow trout $\mathrm{O}$. mykiss after prolonged exposure propiconazole, the levels of lipid peroxidation, CAT and SOD in fish gill were increased whereas significant inhibition of the antioxidant enzymes GPx and GR level and $\mathrm{Na}+, \mathrm{K}+$-ATPase activity was noticed (Li et al., 2011).

Bleaching powder exposure caused the decrease in the specific activity of Glutathione Peroxidase (GPx) and Glutathione Reductase (GR). Decreased level of GSH level could be due to loss of adaptive mechanisms and the oxidation of GSH to GSSH (oxidized GSH) (Yadav et al., 2015). When fish tissues are in contact with the toxicant these were removed by conjugation with GSH directly or by means of GSTs which decreased GSH levels (Singh and Tripathi, 2016). In the present experiment as the concentration of bleaching powder increases the specific activity of GPx decrease (Table 7). Glutathione Reductase (GR) has been suggested as a good biomarker for oxidative stress in fish (Mainak et al., 2017). Glutathione reductase catalyzes the reduction of glutathione disulfide to the sulfhydryl from glutathione, which is a critical molecule in resisting oxidative stress and maintaining the reducing environment of the cell.

There was a negative correlation was observed between the antioxidant enzymes and MDA (Fig. 1 and Table 3) indicating bleaching powder toxicity over antioxidative enzymes. In the present study the specific 
activity of catalase and superoxide dismutase was significantly $(\mathrm{p}<0.001)$ increased in liver and gills whereas the specific activity of glutathione peroxidase and glutathione reductase was significantly $(p<0.001)$ decreased with increase in the concentrations of bleaching powder which varies from 10, 20, 30, 40 and $50 \mathrm{ppm}$ (Table 2).

Histological analysis appears to be a very sensitive parameter and is crucial in determining cellular changes that may occur in target organs such as the gills, liver and kidney (Das and Chandra, 2018). A histological investigation may, therefore, prove to be a cost effective tool to determine the health of fish populations, hence, reflecting the health of an entire aquatic ecosystem in the bio-monitoring process.

In this study, the gill, histology of the fresh water fish, Labeo rohita was analysed. Gill hyperplasia has been regarded as a common sign of chronic toxicity caused by various chemical pollutants (Peebuaa et al., 2006; Hadi and Alwan, 2012). In the present study, mild to moderate hyperplasia was evident after acute and chronic exposure of Labeo rohita due to bleaching powder.

Histological observations on gills of control fingerlings showed normal architecture of primary and secondary lamellae. Whereas fingerlings infected with different concentrations of bleaching powder in gills showed fusion and loss of secondary lamellar epithelium. These pathological changes may be a reaction to bleaching powder intake or an adaptive response to prevent the entry of the pollutants thorough the gill surface. The observed alterations like proliferation of the epithelial cells, partial fusion of some secondary lamellae and epithelial lifting are defense mechanisms, since, in general, these result in the increase of the distance between the external environment and the blood and thus serve as a barrier to the entrance of contaminants.

\section{CONCLUSION}

The present study indicates that bleaching powder induced alterations in the enzymatic activities of the freshwater fish at acute concentration. These alterations can be considered as a tool for biomonitoring of pharmaceutical drug substances in the aquatic environment. However, further studies are needed to understand the risk of bleaching powder using different end points.

\section{ACKNOWLEDGEMENTS}

The researchers are thankful to the Management, Principal and HOD (Zoology), Nowrosjee Wadia College, Pune for providing necessary facilities.

\section{REFERNECES}

Agrahari, S., K.C. Pandey and K. Gopal, 2007. Biochemical alteration induced by monocrotophos in the blood plasma of fish, Channa punctatus (Bloch). Pesticide Biochem. Physiol., 88: 268-272.

Atli, G. and M. Canli, 2010. Response of antioxidant system of freshwater fish Oreochromis niloticus to acute and chronic metal (Cd, $\mathrm{Cu}, \mathrm{Cr}, \mathrm{Zn}, \mathrm{Fe}$ ) exposures. Ecotox. Environ. Safe., 73: 1884-1889.

Basha, P.S., A.U. Rani, 2003. Cadmium-induced antioxidant defense mechanism in freshwater teleost Oreochromis mossambicus (Tilapia). Ecotox. Environ. Saf., 56: 218-221.

Beauchamp, C. and I. Fridovich, 1971. Superoxide dismutase: Improved assays and an assay applicable to acrylamide gels. Anal. Biochem., 44: 276-287.

Butchiram, M.S., M.V. Kumar and K.S. Tilak, 2013. Studies on the histopathological changes in selected tissues of fish Labeo rohita exposed to phenol. J. Environ. Biol., 34: 247-251.

Choo, P.S. and M.J. Williams, 2003. Fisheries production in Asia: Its role in food security and nutrition. NAGA: WorldFish Center Q., 26: 11-16.

Chowdhury, A.K.J., D. Saha, M.B. Hossain, M. Shamsuddin and M.H. Minar, 2012. Chemicals used in freshwater aquaculture with special emphasis to fish health management of Noakhali, Bangladesh. Afr. J. Basic Applied Sci., 4: 110-114.

Das, D.R. and K.J. Chandra, 2018. Seasonal variation of gill, skin, muscle, liver and kidney pathology of Mrigal (Cirrhinus cirrhosus) in cultural pond fisheries, Mymensingh, Bangladesh. Bangladesh J. Vet. Med., 16: 121-129.

Devasagayam, T.P., 1986. Lipid peroxidation in rat uterus. Biochim. Biophys. Acta (BBA)-Lipids Lipid Metab., 876: 507-514.

Goldberg, D.M. and R.J. Spooner, 1983. Glutathione Reductase. In: Methods of Enzymatic Analysis, Bermeyer, H.U. (Ed.). Wiley-VCH, Weinhein, Germany, pp: 277-282.

Hadi, A.A. and S.F. Alwan, 2012. Histopathological changes in gills, liver and kidney of fresh water fish, Tilapia zillii, exposed to aluminum. Int. J. Pharm. Life Sci., 3: 2071-2081.

Hogeboom, G.H., W.C. Schneider and G.E. Pallade, 1948. Cytochemical studies of mammalian tissues I. Isolation of intact mitochondria from rat liver; some biochemical properties of mitochondria and submicroscopic particulate material. J. Biol. Chem., 172: 619-635.

Huang, S.L., Y.M. Weng and C.H. Huang, 2004. Lipid peroxidation in sarcoplasmic reticulum and muscle of tilapia is inhibited by dietary vitamin E supplementation. J. Food Biochem., 28: 101-111. 
Jawahar, A.A., A. Mateen, M.S.A. Kumar and P. Chitrarasu, 2015. Acute toxicity of detergent to Indian major carps Catla catla and Labeo rohita. Eur. J. Exp. Biol., 5: 30-33.

Jeney, G., J. Nemcsok, Z.S. Jeney and J. Olah, 1992. Acute effect of sublethal ammonia concentrations on common carp (Cyprinus carpio L.).II: Effect of ammonia on blood plasma transaminases (GOT,GPT), GIDH enzyme activity and ATP value. Aquacult., 104: 149-156.

Kaoud, H.A. and A.R. El-Dahshan, 2010. Bioaccumulation and histopathological alterations of the heavy metals in Oreochromis niloticus fish. Nature Sci., 8: 147-156.

Lawrence, R.A. and R.F. Burk, 1976. Glutathione peroxidase activity in selenium-deficient rat liver. Biochem. Biophys. Res. Commun., 71: 952-958.

Li, X.B., X.L. Hou, Q. Mao, Y.L. Zhao, Y.X. Cheng and Q. Wang, 2009. Toxic effects of copper on antioxidative and metabolic enzymes of the marine gastropod, Onchidium struma. Arch. Environ. Contam. Toxicol., 56: 776-784.

Li, Z.H., V. Zlabek, J. Velisek, R. Grabic and J. Machova et al., 2011. Antioxidant responses and plasma biochemical characteristics in the freshwater rainbow trout, Oncorhynchus mykiss, after acute exposure to the fungicide propiconazole. Czech J. Anim. Sci., 56: 61-69.

Lowry, O.H., N.J. Rosebrough, A.L. Farr and R.J. Randall, 1951. Protein measurement with the folin phenol reagent. J. Biol. Chem., 193: 265-275.

Mainak, M., M. Mahammed, K. Saheli, D. Debjit and C.S. Bhusan, 2017. Neuronal and oxidative damage in the catfish brain alleviated after Mucuna seed extract treatment. Int. J. Pharmacogn. Phytochem. Res., 9: 52-57.

Malarvizhi, A., C. Kavitha, M. Saravanan and M. Ramesh, 2012. Carbamazepine (CBZ) induced enzymatic stress in gill, liver and muscle of a common carp, Cyprinus carpio. J. King Saud Univ.-Sci., 24: 179-186.

Nabi, S., S. Tanveer and S.A. Ganie, 2017. Glutathione-S-Transferase, Superoxide Dismutase (GST, SOD) levels, protein content and Lipid peroxidation in Schizothorax plagiostomus under the infection of Pomphorhynchus in Nallah sukhnag of Kashmir valley. Pak. J. Biol. Sci., 20: 442-446.

Napierska, D., L.C.J. Thomassen, V. Rabolli, D. Lison and L. Gonzalez et al., 2009. Size-dependent cytotoxicity of monodisperse silica nanoparticles in human endothelial cells. Small, 5: 846-853.

Nemesok, J. and L. Boross, 1999. Comparative studies on the sensitivity of different fish species to metal pollution. Hoto Biol. Hung, 33: 27-27.
Osten, J.R.V., A. Ortiz-Arana, L. Guilhermino and A.M. Soares, 2005. In vivo evaluation of three biomarkers in the Mosquitofish (Gambusia yucatana) exposed to pesticides. Chemosphere, 58: 627-636.

Pacheco, M. and M.A. Santos, 2002. Biotransformation, genotoxic and histopathological effects of environmental contaminants in European eel (Anguilla anguilla L.). Ecotoxicol. Environ. Saf., 53: 331-347.

Rahman, M.M., M.S. Reza, M.N.A. Khan, G.M.M. Rahman, M.N. Islam and M. Kamal, 2013. Influence of bleaching powder on the quality of giant freshwater prawn (Macrobrachium rosenbergii). Food and Nutr. Sci., 4: 1-8.

Rahman, M.Z., A. Khatun, M.I. Kholil and M.M.M. Hossain, 2017. Aqua drugs and chemicals used in fish farms of comilla regions. J. Entomol. Zool Stud., 5: 2462-2473.

Rani, S. and M. Kaushik, 2014. Use of enzymes in detergent on intestinal enzyme activity in fish, Cirrhinus mrigala, Mrigal. Indian J. Fundam. Applied life Sci., 4: 107-109.

Ray, S.N.C. and R.C. Sinha, 2016. Evaluation of ldhIsozymes following the treatment of methyl parathion in the fish, Labeo rohita. Int. J. Pharma. Sci. Invent., 5: 47-51.

Reddy, P.B. and S.S. Rawat, 2013. Assessment of aquatic pollution using histopathology in fish as a protocol. Int. Res. J. Environ. Sci., 2: 79-82.

Reitman, S. and S. Frankel, 1957. A colorimetric method for the determination of serum glutamic oxalacetic and glutamic pyruvic transaminases. Am. J. Clin. Pathol., 28: 56-63.

Salim, M., 2006. Role of fish as food to human nutrition. Proceedings of the International Conference on Solving Problems of Freshwater Fish Farming in Pakistan, November 27-28, 2006, UVAS, Lahore, Pakistan, pp: 20.

Sandhu, A.A. and K.P. Lone, 2003. Food and feeding habits of some catfishes of Pakistan. Pak. J. Zool., 35: 353-356.

Schreck, C.B. and L. Tort, 2016. The concept of stress in fish. Fish Physiol., 35: 1-34.

Schreiber, R., U. Gundel, S. Franz, A. Kuster, B. Rechenberg and R. Altenburger, 2011. Using the fish plasma model for comparative hazard identification for pharmaceuticals in the environment by extrapolation from human therapeutic data. Regul. Toxicol. Pharmacol., 61: 261-275.

Secci, G., G. Parisi, G. Dasilva and I. Medina, 2016. Stress during slaughter increases lipid metabolites and decreases oxidative stability of farmed rainbow trout (Oncorhynchus mykiss) during frozen storage. Food Chem., 190: 5-11.

Singh, N. and M. Tripathi, 2016. Alteration in antioxidant biomolecules after the exposure to fluoride in fresh water fish Heteropneustes fossilis. J. Ecophysiology Occup. Health, 16: 66-71. 
Sinha, R.C. and S.N.C. Ray, 2018. Differential expression of serum LDH isozymes in the fish Labeo rohita as a function of the pesticide carbamate. J. Nanosci Nanotechnol., Vol. 2, No. 2.

Szegletes, T., C.S. Polyhos, T. Balint, A.A. Rady, G. Lang, O. Kufcsak and J. Nemcsok, 1995. In vivo effects of deltamethrin on some biochemical parameters of carp (Cyprinus carpio L.). Environ. Monit. Assess., 35: 97-111.

Thophon, S., M. Kruatrachue, E.S. Upatham, P. Pokethitiyook, S. Sahaphong and S. Jaritkhuan, 2003. Histopathological alterations of white seabass, Lates calcarifer, in acute and subchronic cadmium exposure. Environ. Pollut., 121: 307-320.

Tugiyono and M.M. Gagnon, 2002. Metabolic enzymes as biochemical markers of effect following exposure of fish to sodium pentachlorophenate (Na-PCP). Bull. Environ. Contam. Toxicol., 69: 570-575.
Vutukuru, S.S., S. Chintada, K.R. Madhavi, J.V. Rao and Y. Anjaneyulu, 2006. Acute effects of copper on superoxide dismutase, catalase and Lipid peroxidation in the freshwater teleost fish, Esomus danricus. Fish Physiol. Biochem., 32: 221-229.

Wahlefeld, A.W., 1983. UV-Method with L-Lactate and NAD. In: Methods of Enzymatic Analysis, Bergmeyer, H.U. (Ed.). Verlag GmbH \& Co. KGaA, Weinheim, Germany, pp: 126-32.

Yadav, S.S., R. Kumar, P. Khare and M. Tripathi, 2015. Oxidative stress biomarkers in the freshwater fish, Heteropneustes fossilis (Bloch) exposed to sodium fluoride: Antioxidant defense and role of ascorbic acid. Toxicol. Int., 22: 71-76. 